\title{
AMBIENT AIR QUALITY IN AN URBAN AREA AND ITS EFFECTS ON PLANTS AND HUMAN BEINGS: A CASE STUDY OF TIRUCHIRAPPALLI, INDIA
}

\author{
Sirajuddin. M. Horaginamani*, M. Ravichandran \\ Department of Environmental Management, School of Environmental Sciences, \\ Bharathidasan University, Tiruchirappalli-24, Tamil Nadu \\ *Corresponding author: ecosirajuddin@yahoo.com \\ Received 03 December, 2009; Revised 12 April, 2010
}

\begin{abstract}
Though water and land pollution is very dangerous, air pollution has its own peculiarities, due to its transboundary dispersion of pollutants over the entire world. In any well planned urban set up, industrial pollution takes a back seat and vehicular emissions take precedence as the major cause of urban air pollution. Air pollution is one of the serious problems faced by the people globally, especially in urban areas of developing countries like India. All these in turn lead to an increase in the air pollution levels and have adverse effects on the health of people and plants. Western countries have conducted several studies in this area, but there are only a few studies in developing countries like India. A study on ambient air quality in Tiruchirappalli urban area and its possible effects selected plants and human health has been undertaken, which may be helpful to bring out possible control measures.
\end{abstract}

Keywords: ambient air quality, respiratory disorders, APTI, human health

\section{INTRODUCTION}

It is known fact that $60 \%$ of air pollution in city is caused by automobiles only. The effect of these pollutants is observed at acute level on sensitive species both plants and animals. Plants are considers for investigation of effect of auto exhaust pollutants. Response of plants towards air is being assessed by air pollution tolerance index. Acute and chronic symptoms were observed to support the investigation regarding accumulation of pollutants. Some plant species and varieties are so sensitive that they can be conveniently employed as biological indicators or monitors of specific pollutants. They can further assist planner in managing the urban cities.

Human health is very closely linked to environmental quality, as the Etiology of most of the human diseases being related to the status of the living environment of man. According to statistics, $25 \%$ of all preventable illnesses are caused by detrimental environmental factors [UNEP, United Nations Children's Fund, WHO 2002]. In Africa, the environmental influence on disease incidence is even higher, being about $35 \%$ (Gopalan H.N.B, 2003). Both the developed and developing countries are faced with the problems related to environmental pollution, caused by anthropogenic activities of man, disturbing the habitat around. Smoky indoor air, polluted ambient air, poor sanitation and 
contaminated water play a crucial role in causing ill health. Existing cities are expanding, new cities are being created, and adjacent cities are merging. As a transportation systems are increasing everywhere. Therefore, air pollution has become a growing problem in cities through out the globe, and transportation is recognized as the major source of air pollution in many cities. In developing countries the air quality crisis in cities often attributes in large measures (40-80\%) to vehicular emission. Despite the improved performance of technology is presently insufficient to counteract the growth of vehicles (Anon., 1980) and associated pollution problems. Thus, it is necessary to evaluate the status of urban air pollution continuously and to assess its impact on human health and plants. So that proper mitigative measures can be implemented.

\section{MATERIALS AND METHODS}

The study has been done in the Tiruchirappalli city $\left(10.5^{\circ} \mathrm{N}, 78.43^{\circ} \mathrm{E}, 78.8 \mathrm{MSL}\right)$, situated on the banks of the river Cauvery, India. It is the fourth largest city in Tamil Nadu. It spreads over an area of $146.90 \mathrm{sq}$. Km with total population of above 7, 50,000. Tiruchirappalli the fourth largest city of Tamil Nadu is very rapidly growing in terms of its population and number of vehicles. The 4 major highways $\mathrm{NH} \mathrm{45,} \mathrm{NH} \mathrm{67,}$ NH 210 and NH 277 pass trough the city. The heavy traffic on these highways has been significantly contributed to air pollution in the city.

Ambient air quality was monitored for major air pollutants viz Suspended Particulate Matter (SPM), Sulphur dioxide $\left(\mathrm{SO}_{2}\right)$ and Oxides of Nitrogen $\left(\mathrm{NO}_{\mathrm{X}}\right)$.High volume sampler (Envirotech APM-430) is used for sampling. $\mathrm{SO}_{2}$ and $\mathrm{NO}_{\mathrm{X}}$ were absorbed in Sodium tetrachloromercurate and Sodium hydroxide. Analysis of this solution by West and Gaeke method, and Griess - Saltzman method, respectively. SPM was collected on pre weighed glass fiber filter (Whatman).Filter paper was again weighed after sampling and the difference in weight were used to calculate concentrations of SPM in respective areas and expressed as $\mu \mathrm{g} / \mathrm{m} 3$ of air. The monitoring was done for 24 hours. This research work was carried out from August 2008 to January 2009 (Six months). Eight sampling stations were selected to represent 8 different traffic volumes and activities. They are Central bus stand, Chattram bus stand, Puthur, Palakarai, Srirangam, Main guard gate, TVS toll gate and Old Paalpanne Circle. Leaf samples were collected from 15 different plants growing commonly in traffic areas of Tiruchirappalli city and their Air pollution tolerance index (APTI) was determined (Singh and Rao 1983). The Polythene bags were used for storing leaf samples during transportation. The leaf samples were refrigerated at about $20^{\circ} \mathrm{C}$, when they had to be stored. The samples were estimated for Leaf-extract pH (Singh and Rao 1983), relative moisture content (Wealtherly, 1965), total chlorophyll (Arnon, 1949) and ascorbic acid (Keller and Schwanger, 1977). Estimation of Leaf-extract $\mathrm{pH}$ : $0.5 \mathrm{~g}$ of leaf material was ground to paste and dissolved in $50 \mathrm{ml}$ of distilled water and Leaf-extract $\mathrm{pH}$ was measured by using calibrated digital $\mathrm{pH}$ meter. Estimation of relative moisture content: Fresh leaf samples collected from the study area and were brought immediately to the laboratory and washed thoroughly. The excess water was removed with the help of filter paper. The initial weight of samples were taken $\left(\mathrm{W} 1 \mathrm{~g}\right.$ ) and kept in oven at $60^{\circ} \mathrm{C}$ until constant weight was obtained and the final weight was taken (W2 g).Total Chlorophyll was estimated by acetone extraction method and ascorbic acid was estimated by 2,6-dichlorophenol indophenol's dye method. APTI given 
by $\mathrm{APTI}=\{[\mathrm{A}(\mathrm{T}+\mathrm{P})+\mathrm{R}] / 10\}$. Where $\mathrm{A}$ is the ascorbic acid in $\mathrm{mg} / \mathrm{g} ; \mathrm{T}$ is the total chlorophyll in $\mathrm{mg} / \mathrm{g}$; $\mathrm{P}$ is $\mathrm{pH}$ of leaf sample; and $\mathrm{R}$ is relative water content in $\mathrm{mg} / \mathrm{g}$. Data related to adverse effects of vehicular pollution on human health in eight different locations of Tiruchirappalli has been collected by the 'Questionnaire method', covering many individuals. A questionnaire was prepared and survey was conducted particularly in case of suspected allergic population by inquiring the recurrence of the type of allergic symptoms and other respiratory diseases. The occasions of this onset was recorded with each individual to assess the allergic status. The secondary data were collected from various health centers, hospitals and clinics which belong to the area under study.

\section{RESULTS \& DISCUSSION}

Table-1 shows average concentrations of $\mathrm{SPM}, \mathrm{SO}_{2}$ and $\mathrm{NO}_{\mathrm{X}}$ at each sampling station. The highest concentration of $\mathrm{SPM}, \mathrm{SO}_{2}$ is recorded at Palakarai, while the highest $\mathrm{NO}_{\mathrm{X}}$ concentrations are recorded at Chattram bus stand. SPM concentrations ranged from 417.81 to $1400.49 \mu \mathrm{g} / \mathrm{m}^{3} . \mathrm{SO}_{2}$ concentrations ranged from 10.88 to $33.70 \mu \mathrm{g} / \mathrm{m}^{3}$.NOx concentrations ranged from 132.22 to $177.01 \mu \mathrm{g} / \mathrm{m}^{3}$.

Table: 1 Average concentration of SPM, $\mathrm{SO}_{2}$ and $\mathrm{NOx}\left(\mu \mathrm{g} / \mathrm{m}^{3}\right)$ at sampling stations

\begin{tabular}{|l|l|l|l|}
\hline Sampling Station & SPM & SO2 & NOx \\
\hline Central Bus Stand & 1111.38 & 23.78 & 173.69 \\
\hline Chattram Bus Stand & 1400.49 & 19.05 & 177.01 \\
\hline Puthur & 417.81 & 13.01 & 166.90 \\
\hline Palakarai & 1324.96 & 33.70 & 171.26 \\
\hline Srirangam & 863.63 & 10.88 & 132.22 \\
\hline Main Guard Gate & 924.40 & 19.21 & 164.73 \\
\hline TVS Toll Gate & 1102.04 & 19.70 & 167.43 \\
\hline Old Paalpanne Circle & 991.61 & 18.29 & 119.55 \\
\hline
\end{tabular}

Except Puttur SPM concentrations exceeded ambient air quality standards of Central pollution control board (CPCB) at all sampling stations. High traffic volume in this region is major reason for these high values. But SO2 is well within the standards of CPCB all sites. Whereas NOX concentrations exceeded quality standards of CPCB at all sampling stations except Srirangam.

The air pollution tolerance index (APTI) value of 15 different plants growing commonly in traffic area of the city is given in table 2. In the present study the maximum APTI is observed in Azadirachta indica 12.95 and minimum in Enterolobium saman 7.12 (Table 1). Nrusimha et al., (2005) have studied the APTI of many plant species and established the maximum APTI value for Azadirachta indica to be 16.50 and minimum in 
Pongamia glabra. Agarwal et al., (1991) studied APTI of some selected plants and described Mangifera indica as reliable bioaccumlator plant. Rao (1972), Agarwal and Agarwal (1988) also reported high sensitivity of Mangifera indica, Azadirachta indica, Psidium guajava, Mangifera indica, Bougainvillea glabra, Lagerstroemia indica, Morinda tinctoria, Hibiscus rosasinensis, Ixora coccinea, Polyalthia longifolia, Achras sapota and Cassia fistula are reported high APTI values and considered as tolerant plant.

Table: 2 APTI of some selected plant species

\begin{tabular}{|l|l|l|l|l|l|}
\hline $\begin{array}{l}\text { Name of the plant } \\
\text { Species }\end{array}$ & $\mathrm{pH}$ & $\begin{array}{l}\text { \% of } \\
\text { Relative } \\
\text { moisture } \\
\text { content }\end{array}$ & $\begin{array}{l}\text { Total } \\
\text { Chlorophyll } \\
\mathrm{mg} / \mathrm{g}\end{array}$ & $\begin{array}{l}\text { Ascorbic } \\
\text { acid mg/g }\end{array}$ & APTI \\
\hline Achras sapota & 4.3 & 88.22 & 0.97 & 1.71 & 9.72 \\
\hline Azadirachta indica & 5.9 & 90.77 & 0.42 & 6.14 & 12.95 \\
\hline Bauhinia purpurea & 4.1 & 87.39 & 0.40 & 0.70 & 9.05 \\
\hline Bougainvillea glabra & 5.5 & 90.56 & 1.56 & 2.80 & 11.03 \\
\hline Cassia fistula & 4.2 & 80.01 & 0.30 & 3.23 & 9.45 \\
\hline Citrus aurantifolia & 3.9 & 79.00 & 0.24 & 1.89 & 8.68 \\
\hline Enterolobium saman & 4.9 & 65.31 & 0.69 & 1.07 & 7.12 \\
\hline Hibiscus rosasinensis & 4.2 & 91.49 & 0.71 & 2.40 & 10.32 \\
\hline Lagerstroemia indica & 4.2 & 84.94 & 1.60 & 3.51 & 10.52 \\
\hline Mangifera indica & 6.9 & 81.43 & 0.50 & 5.10 & 11.91 \\
\hline Morinda tinctoria & 4.7 & 90.93 & 0.26 & 2.41 & 10.28 \\
\hline Polyalthia longifolia & 5.2 & 90.99 & 0.18 & 1.43 & 9.86 \\
\hline Pongamia glabra & 4.4 & 84.30 & 0.38 & 0.93 & 8.87 \\
\hline Psidium guajava & 6.6 & 81.97 & 0.21 & 6.64 & 12.71 \\
\hline
\end{tabular}

Total exposure to an individual to a specific pollutant is determined by the concentration of contaminant and the duration of its exposure (Spengler and Dockery,1981). Exposure to indoor and outdoor air quality is different because they always change with time and diurnal pattern (TERI, 1995). Exposure to SPM is also an equally serious risk to health SPM includes all air-borne particles in the size range of $0.5 \mu$ to $100 \mu$. The actual health damage caused by dust particles depends upon its nature and composition (Binder et al., 1976). The effects attributed to mild eye irritation mortality (David,1995). The data generated from the survey were analysed to assess the percentage of allergic population and the suspected allergy causing agents. The results are shown in Table-3.The assessment of respiratory disorders (RDs) was obtained from the questionnaire survey from the doctors. On the basis of the survey of the SPM-related RDs each disease was recorded for indexing the imprint class I to IV. The highest imprint score depicts the maximum severity of RDs. 
Table: 3 Estimation of allergic symptoms

\begin{tabular}{|c|c|c|c|c|}
\hline Complaint & Total no. cases & Condition & No. of person & Percent of incidence. \\
\hline \multirow[t]{2}{*}{ Neck block } & \multirow[t]{2}{*}{20} & Allergic & 17 & 85 \\
\hline & & Non- Allergic & 3 & 15 \\
\hline \multirow[t]{2}{*}{ Sneezing } & \multirow[t]{2}{*}{35} & Allergic & 30 & 86 \\
\hline & & Non- Allergic & 5 & 14 \\
\hline \multirow[t]{2}{*}{ Cough } & \multirow[t]{2}{*}{60} & Allergic & 50 & 83 \\
\hline & & Non- Allergic & 10 & 17 \\
\hline \multirow[t]{2}{*}{ Hyperacidity } & \multirow[t]{2}{*}{29} & Allergic & 18 & 62 \\
\hline & & Non- Allergic & 11 & 38 \\
\hline
\end{tabular}

Table: 4 Imprint classifications of respiratory diseases

\begin{tabular}{|l|l|}
\hline Imprint score & Symptoms \\
\hline 0.0 & No RD: healthy, free from any respiratory disease \\
\hline 2.5 & Mild RD: suffering from only upper track respiratory infections (UTRI) \\
\hline 5.0 & $\begin{array}{l}\text { Moderate RD: suffering from UTRI as well as lowest track respiratory } \\
\text { infections }\end{array}$ \\
\hline 10.0 & $\begin{array}{l}\text { Severe RD: Suffering from bronchitis, asthma, allergic thintis, fibrosis, } \\
\text { asbestosis, pneumoconiosis and non-malignant RDs }\end{array}$ \\
\hline
\end{tabular}

\section{CONCLUSION}

From the results, it can be concluded that Suspended Particulate Matter (SPM) is the main pollutant within the Tiruchirappalli city. Except at Puthur, in all eight sampling stations, the concentration of SPM exceeded the ambient air quality standard by CPCB . The reason is being the growing number of automobiles and poorly and congested road with heavy traffic. This problem can be overcome by adapting advance eco-friendly transport systems, usesage biofuels and widening of roads. The plants with low APTI 
value like Bauhinia, Pongamia, Citrus and Enterolobium were categorized as sensitive and plants with high APTI value like Azadirachta, Psidium, Mongifera, Bougainvillea, Largerstromia, Morinda, Hibiscus, Ixora, Polyalthia, Achras and Cassia as tolerant. Further studies on Air pollution tolerance index in respect to different areas of Tiruchirappalli city are required to find out the tolerance of various plants to air pollutants. The study reveals that urban air pollutants have adverse effects on human health. In Tiruchirappalli city, many individuals residing near by traffic intersections are suffering from respiratory diseases. Proper environmental awareness and personal protective devices may be useful in avoiding health problems.

\section{REFERENCES}

1. Agarwal, Madhoolika.1985. Plant factors as indicator of $\mathrm{SO}_{2}$ and $\mathrm{O}_{3}$. In Biological monitoring of state the environment (bioindicator).Indian National Science, New Delhi. pp 225-231.

2. Agarwal, M. and S. B. Agarwal 1988. Phytomonitoring of air pollution around a thermal power plant.Atoms.Env., 22 (in press).

3. Agarwal, S. K and D. C. Bhatnagar 1991. Auto Vehicular air pollution induce pigment and ascorbic acid changes in avenue plants. Acto Ecologica, 13(1) CK: 1-4.

4. Anon.: 1997a. Monitoring of Human Exposure to Air Pollution in Highly Industrial Area, Central Pollution Control Board, New Delhi.

5. Anon, 1997b. Motor Vehicle Facts and Figures, American Automobile Manufacturers Association, Detroit, Michigan.

6. APHA, 1977. Methods of Air Sampling and Analysis, 2nd ed., APHA, Washington.

7. Arnon, D. S. 1949. Copper enzymes in isolated chloroplast. Polyphenoxiase in Beta Vulgaris Plant Physiology., 24;1-15.

8. Arruda, L. K., Mann, B. J. and Chapman, M. D. 1992. 'Selective expression of a major allergen and cytotoxin aspergillus fumigates', J. Immunol. 149, 3554-3559.

9. Banerjee, S. K., Dhar, R. K. and Ghose, M. K. 1996. 'Air pollution due to coal washery projects and its abatement measures', Environ. Manag. 20(2), 235-240.

10. Dubey, P. S. and K. Pawar. 1985. Air Pollution and plant response-review. In prospective in environmental botany (vol 1).Ed D.N.Rao, K.J.Ahemad, M.Yunus and S.N.Singh. Print House, Lucknow. pp 101-118.

11. Ghose, M. K. 1989. 'Pollution due to air borne dust particles in coal mining, its monitoring and abatement measures', Minetech 10(1), 91-95.

12. Ghose, M. K. and Banerjee, S. K.: 1995. 'Status of air pollution caused by coal washery project in India', Environ. Monit. Assess. 38, 97-105. 
13. Ghose, M. K. and Majee, S. R., 2000a. 'Status of air pollution in Indian opencast coal mines', Minetech 21(2), 48-52.

14. Ghose, M. K. and Majee, S. R. 2000b. 'Assessment of impact on air environment due to opencast coal mining - an Indian case study’, Atmos. Environ. 34, 2791-2796.

15. Ghose, M. K. and Majee, S. R. 2001. 'Air pollution due to coal mining and its control in Indian Context', J. Sci. Indus. Res. 60, 786-797.

16. Ghose, M. K., Majee, S. R. and Sinha, P. K. 1999. 'Monitoring and assessment of impact on air environment due to hard coke plant operation-an Indian case study', Int. J. Environ. Stud. 56(4), 1-8.

17. Gopalan, H. N. B. 2003. Environmental health in developing countries: an overview of the problems and capacities, Environmental Health Perspectives, 111:A446.

18. Karim, M. and Ohmo, T. 2000. 'Air quality planning and empirical model to evaluate SPM concentration’ ,J. Environ. Eng. December, 1116-1124.

19. Kazimuddin, A. and Banerjee, L. 2000. 'Fighting for Air', Down to Earth, July 31.

20. Keller, T. and H. Schwanger 1977. Air pollution and ascorbic acid. European J. for Pathology, 7; 338-350.

21. Nrusimha, T., K. Suresh Kumar and Srinivas. N., 2005. Air pollution tolerance index of tree species growing in industrial and traffic areas of Visakhapatinam. Indian. J.Env.Protection.25;1057-1060.

22. Singh, S. K and D. N. Rao. 1983. Evaluation of plants for their tolerance to air pollution. Sympo.on Air Pollution Control. New Delhi, Proceedings, pp 218-224.

23. Steinberg, J. J., Janet, L. and Gilson, D. G. 1991. 'The patho-biology of ozoneincluding damage',Arc. Environ. Health 46, 80-87.

24. TERI 1995. Health Risk and Cost Effective Interventions for Indoor Air Pollution A Report, Tata Energy Research Institute, New Delhi.

25. Tilak, J. 1989. 'Mites and mite allergy as risk factor for asthma', Ann. Allergy 63, 392-397.

26. Tiwari, S., S. Bansal and S. Rai.1993. Expected performance indices of some planted tree of Bhopal. Indian J.Env.Health.35; 282-286. 